Pak. J. Agri., Agril. Engg., Vet. Sci., 2021, 37 (1): 49-55

ISSN: 1023-1072 (Print), ISSN: 2663-7863 (Online)

https://doi.org/10.47432/2020.37.1.7

\title{
PREVALENCE OF SUBCLINICAL MASTITIS, ASSOCIATED RISK FACTORS AND ANTIBIOTIC SENSITIVITY OF ESCHERICHIA COLI AND STAPHYLOCOCCUS AUREUS IN CATTLE IN MULTAN, PAKISTAN
}

\author{
T. Ahmed ${ }^{1}$, M. Kashif ${ }^{\star}$, E. Ahmad ${ }^{1}$, M. Nadeem ${ }^{3}$ and M. Rizwan ${ }^{4}$ \\ ${ }^{1}$ Department of Clinical Sciences, Bahauddin Zakariya University, Multan, Pakistan \\ ${ }^{2}$ Department of Clinical Sciences, College of Veterinary and Animal Sciences, Jhang, Pakistan \\ ${ }^{3}$ College of Veterinary Sciences, Arid Agriculture University, Rawalpindi, Pakistan \\ ${ }^{4}$ College of Veterinary Sciences, Bahauddin Zakariya University, Bahadur Campus Layyah, Pakistan
}

\begin{abstract}
Mastitis is the most widespread and economically important disease of dairy sector worldwide. The present research was, therefore intended to establish the prevalence of mastitis in and around the Multan district. A total of 100 dairy cows were randomly sampled during the period from July 2018 to October 2018 from different local dairy farms at Multan. After screening with California Mastitis Test, milk samples from mastitic animals were cultured and subjected to microbiological examination. The overall prevalence of subclinical mastitis in cows was $38 \%$ and quarter-wise prevalence of subclinical mastitis was $36.20 \%$.. Mastitis in front left quarters was $34.40 \%$, right front quarters $31.60 \%$, while left rare quarters $41 \%$ and right rear quarters 38\%. Bacteria Staphylococcus, Streptococcus, Corynebacterium, Enterococci, Salmonella, Bacillus, Klebsiella, and Pseudomonas were isolated from infected samples. Staphylococcus aureus was the top-ranking isolated bacteria followed by Strept. Agalactiae and E. coli. The lack of proper milking techniques and no teat dipping were the most significantly associated risk factors. In the current study, E. coli isolates were sensitive to Gentamycine, Streptomycin, Chlororamphenicol and Kanamycin while resistant to Vancomycin and Penicillin. Similarly, S. aureus was extremely susceptible to Chloramphenicol, Vancomycin and Kanamycin but resistant to Tetracycline and Penicillin. It was concluded that subclinical mastitis was widely prevalent in Multan city. This study will help the farmers to adopt effective measures to control mastitis regarding the risk factors.
\end{abstract}

Keywords: bacteria, gentamycin, prevalence, subclinical mastitis, treatment

\section{INTRODUCTION}

Mastitis (inflammatory reaction of the udder tissues) is the most widespread and most important disease of economic interest in the dairy sector worldwide (Biswadeep et al., 2015). At the very least, each fourth dairy buffalo and cow is bothered by this condition (Hoque et al., 2015). Current losses figures due to this infection are not available in Pakistan, although it was assessed in 1978 that in the Punjab province alone the overall losses about Rs.240 million per year due to clinical mastitis (Ashfaq et al., 2015). It is worth noting that the subclinical type of mastitis is 15-40 times more common than its clinical equivalent. These casualties are primarily due to Streptococcus agalactiae, produced by Escherichia coli, Staphylococcus aureus, and Corynebacterium

*Corresponding author: muhammad.kashif@uvas.edu.pk pyogenes. The clinical form of mastitis possesses all the five key signs of inflammation like redness, pain, heat, swelling, and loss of milk production, while the sub-clinical mastitis lacks all signs of inflammation. Sub-clinical mastitis can be detected by applying direct (Somatic Cell Count; SCC) or indirect (California Mastitis Test; CMT or others).

Sub-clinical mastitis is responsible for 60$70 \%$ of economic losses to the dairy industry of the USA (Huirong et al., 2019). This disease causes annual losses of about US\$ 35 billion world-widely. Field studies have also shown that mastitis is among the most significant animal health concerns to become a serious livestock disease in Pakistan (Welderufael et al., 2016; Rohmeier et al., 2020). The higher losses with this disease might be due to a lack of mastitis prevention measures like teat dipping and dry period antibiotic treatment (Dagmara et al., 
2020). It is important to remember that this research did not report losses caused by subclinical mastitis, a type of mastitis that is $3-40$ times most prevalent than clinical mastitis and causes the highest general decrease in many other dairy farms (Dorota et al., 2020). Subclinical mastitis is confirmed by laboratory analysis of milk or animal tests as there is no noticeable swelling of the udders or milk anomalies. It is a well-known fact that every buffalo or cow develops mastitis before she expires. Mastitis can be controlled more effectively if prevalence is known in the animal population and area. Thus, the current research was designed to examine the animal-wise and quarter-wise occurrence of sub-clinical mastitis, its associated risk factors and antibiotic sensitivity of isolates of $S$. aureus and $E$. coli in and around Multan city.

\section{MATERIALS AND METHODS}

\section{Study Area and selection of animals}

Multan city is located on the banks of River Chenab and the center of south Punjab. The geographical location of Multan is 3721 square kilometers. It has three tehsils i.e. Multan, Jalapur peer wala, and Shujaabad. Among all cattle population, Sahiwal and Crossbreed cattle are the main breeds of this region. In this study, a total of 100 dairy cows were randomized sampled during the period from July 2018 to October 2018 from different local dairy farms at Multan. A predesigned questionnaire proforma was administered to owners to collect the information to assess the risk factors associated with mastitis.

\section{Collection and transportation of milk sample}

The Procedure for collecting quarter foremilk samples identified by National Mastitis Council Inc., U.S.A. (1990) was observed. The sterile disposable syringes of $5 \mathrm{ml}$ capacity, labelled as LF (left front), LR (left rear) RF (Right front) and RR (Right rear), were used. Every teat was washed with cotton soaked with $70 \%$ ethanol. A different pledge was used for each teat. For every teat, a separate pledged was used. About 4-5 $\mathrm{ml}$ of milk was collected aseptically after discarding the first few streams. For microbiological analysis, collected samples were rapidly cooled in the icebox and directed to the Laboratory, Department of Clinical Sciences, FVS, BZU, Multan. California Mastitis Test (CMT) was performed to confirm the mastitis (Kashif et al., 2013). Briefly, milk samples from the individual quarter and test solution were mixed in the same quantity in Petri dishes. The change in the consistency of milk ranging from mild flakes to gel formation indicated mastitis while no change in milk consistency indicated mastitis free animal.

\section{Bacteriological examination}

CMT positive samples were used for microbiological analysis. Microbiological analysis of milk specimens was started around eight hours after the collection of samples. MacConkey's agar and Blood agar were applied for the growth of bacteria. To achieve a secure dispersion of pathogens, the samples were shaken eight times. By using a platinum-rhodium loop. About $0.01 \mathrm{ml}$ of each milk sample was streaked onto the blood agar plate. Milk specimens from all quarters were grown on the $100 \mathrm{~mm}$ plate by placing each quarter sample on (one-fourth of an area) of the plate and incubated for 48 hours at $37^{\circ} \mathrm{C}$. When five or more identical colonies were present on the plate, the quarter was estimated affected. In order to identify a sample as infected or compromised, National Mastitis Council Inc., (1987) recommendations on the importance of colony numbers in pure or mixed cultures were used.

\section{Identification and Purification of Bacteria Identification and purification were done by automatic method (Vitek ${ }^{\circledR} 2$ Compact, Biomérieux, France). Gram negative and positive bacteria were identified using the GN ID and the GP ID card. It was carried out in accordance with the procedures mentioned by the manufacturer.}

\section{Antibiotic sensitivity testing}

Antibiotic discs were added to the surface of the inoculated agar plates. (Inoculated with the standardization of bacterial suspension using McFarland standards) using aseptic technique. Approximately seven antimicrobials such as Gentamycin, chloroamphenicol, Vancomycin, Penicillin, Tetracycline, Kanamycin and Streptomycin (Oxoid, Hampshire, England) were selected from the main class of antimicrobials and checked for sensitivity. Every disc was pressed down to ensure maximum contact with the agar surface. After measuring the inhibition region, it was classified as sensitive, intermediate, and resistant.

\section{Data analysis}

The quarter wise prevalence was determined by dividing the number of positive quarters over the 
total number of quarters tested. The chi-square value was used to find the significant difference among risk factors and variables. P-value $\leq 0.05$ were considered statistically for all analysis.

\section{RESULTS}

Animal-wise prevalence of subclinical mastitis in cows was $38 \%$ depicted by Table I and the quarter wise prevalence of subclinical mastitis was $36.20 \%$ as shown in Table II. It further showed 34.4 in RF, $31.60 \%$ in LF, $41 \%$ in RR, and $38 \%$ in LF. The results showed that the incidence of subclinical mastitis was higher in the rear teat as compared to the front teat.

Table 1. Animal wise mastitis prevalence in dairy cows

\begin{tabular}{|l|l|l|l|}
\hline $\begin{array}{l}\text { Total } \\
\text { No. of } \\
\text { animals }\end{array}$ & $\begin{array}{l}\text { CMT } \\
\text { Positive } \\
\text { animals }\end{array}$ & $\begin{array}{l}\text { Total No. of } \\
\text { animals/affected } \\
\text { animals }\end{array}$ & $\%$ Prevalence \\
\hline 100 & 38 & $38 / 100$ & $38 \%$ \\
\hline
\end{tabular}

Table 2. Quarters wise mastitis prevalence in dairy cows

\begin{tabular}{|l|l|l|l|l|}
\hline Quarters & $\begin{array}{l}\text { Total } \\
\text { quarters } \\
\text { examined }\end{array}$ & $\begin{array}{l}\text { Blind } \\
\text { Quarters } \\
\text { (showing } \\
\text { no. } \\
\text { secretion) }\end{array}$ & $\begin{array}{l}\text { Positive } \\
\text { no. of } \\
\text { quarters/ } \\
\text { total } \\
\text { quarters } \\
\text { examined }\end{array}$ & \% Prevalence \\
\hline RF & 099 & 01 & 033 & $34.04 \%$ \\
\hline LF & 098 & 02 & 031 & $31.60 \%$ \\
\hline RR & 096 & 04 & 040 & $41.00 \%$ \\
\hline LR & 097 & 03 & 037 & $38.00 \%$ \\
\hline $\begin{array}{l}\text { Total } \\
\text { quarters }\end{array}$ & 390 & 10 & 141 & $36.90 \%$ \\
\hline
\end{tabular}

S. aureus $(32.66 \%)$ was isolated from cases positive for mastitis in the present study as a top-ranking pathogen, followed by Strep. agalactiae (18.36\%) and E. coli $(20.40 \%)$ depicted in Table 3.

Table 3. Most prevalent bacteria species isolated from mastitis quarters

\begin{tabular}{|l|l|l|}
\hline Bacteria & Out of total & Prevalence \\
\hline Staphylococcus aureus & $16 / 49$ & 32.66 \\
\hline Streptococcus agalactiae & $9 / 49$ & 18.36 \\
\hline E. coli & $10 / 49$ & 20.40 \\
\hline
\end{tabular}

Risk factors associatedwere the management factors such as housing, production system, floor type, proper milking techniques, udder washing prior to milking, routine mastitis testing with $\mathrm{CMT}$, and the use of teat dipping. Cow factors included were the breed and history of mastitis. A description of the frequency of all variables of the survey considered in the analysis was given in Table 4. Among the risk factors examined, use of teat dips, udder drying towel for each cow history of mastitis and routine testing for mastitis was significantly correlated with the presence of mastitis $(p<0.05)$. The results showed that the prevalence was higher in the semi-intensive production system $(46.6 \%)$ than the int ensive production system (34.2\%). In relation to floor type, the prevalence was significantly higher in the earthen floor $(60 \%)$ than concrete type floor $(30.6 \%)$. Based on the interval in the cleaning of the floor, the prevalence was significantly higher in weekly cleaning $(60 \%)$ than daily cleaning $(32.5 \%)$ of the floor. About teat dipping, the infection rate was higher $(41.6 \%)$ in those animals in which teat dipping was not performed (30\%). Concerning the breed of the animal, the prevalence was significantly higher in exotic $(40 \%)$ than crossbred $(65.7 \%)$ animals. The association of infection decreased with proper milking techniques. In this research, mastitis was more likely to occur in cows with a prior history of mastitis than in cows without an earlier history of mastitis.

From total positive samples, 10 and 15 isolates of E.coli and $S$. aureus respectively were tested for susceptibility to seven different antimicrobial discs. The $E$. coli isolates were sensitive to Gentamycine (100\%), Streptomycin (100\%), Chlororamphenicol (60\%) and Kanamycin $(70 \%)$. Whereas intermediate to Tetracyclin (40\%) and resistant to Chloloromphenicol (40\%), Vancomycin (100\%), Kanamycin (30\%), Penicillin (100\%) and Tetracycline $(60 \%)$. S. aureus isolates were sensitive to Chloramphenicol (100\%), Vancomycin (100\%), Kanamycin (100\%) and Gentamycin (13.3\%) whereas intermediate to Streptomycin $(20 \%)$ and showed resistance to Tetracycline, Penicillin as shown in Table 5.

\section{DISCUSSION}

Subclinical mastitis is one of the most significant cattle and buffalo infections that cause economic losses in dairy farming, and the incidence is growing day by day. The bacterial origin is at the forefront of many causes of mastitis. The quarter-wise overall occurrence was $36.2 \%$ and animal-wise prevalence was $38 \%$ in cows of subclinical mastitis. A previous study has shown the prevalence of clinical and sub-clinical mastitis was $12.5 \%$ and $51.8 \%$ at cow level and $10.7 \%$ and $46.4 \%$ at the quarter level by CMT, SFMT, and WST, respectively (Zeryehun and Gerema, 2017). Although herd-mate cows showed a greater rate of mastitis (sub-clinical) in cows $(75 \%)$ and individually controlled animals at 44.44 percent. (Abebe et al., 2016) revealed the occurrence of $74.7 \%$ in cows based on the White Side Test and CMT. (Amer et al., 2018) used cultural analysis and identified $74.7 \%$ infection in cows at the herd level. (Patil et al., 
$2015)$ recorded incidence $(59.2 \%)$ and $(36.8 \%)$ of subclinical mastitis in buffaloes and cows. (Christine et al., 2020) detected occurrence of mastitis $80 \%$ in cows, out of which $6.8 \%$ was clinical mastitis, while subclinical was $73.1 \%$. (Kavitha et al., 2009) utilized the Ciba-Geigy Mastitis Test and detected that $34.48 \%$ buffaloes were affected by sub-clinical mastitis. (Motaung et al., 2017) have investigated an occurrence of $30 \%$ in buffaloes after using $\mathrm{pH}$ test, white Side test and Strip Cup test. (Rohmeier et al., 2020) also published that total animal-wise occurrence was $44 \%$ while the quarter-wise prevalence was $44.1 \%$ in cows based on Surf Field Mastitis Test. (Dorota et al., 2020) estimated the total occurrence of subclinical mastitis $36 \%$ in crossbred cows and $27 \%$ in buffaloes by using microbiological testing of milk and the Surf Field Mastitis Test. The animal-wise prevalence was observed to be $45 \%$ while the quarter-wise prevalence was $35.25 \%$ (Bachaya et al., 2011). Differences in management strategies, detection methods, breeds of animal, conditions at the environment and immune responses of animals may be the cause of the variation in the predominance of subclinical mastitis in current and recent studies. Extreme weather promotes the disease and induces stress to the body, thereby decreasing immunity, contributing to an increased subclinical incidence associated with infectious and environmental mastitogens. Several earlier studies (Cha et al., 2011; DeVliegher et al., 2012) demonstrated that great management diminishes the rate of mastitis to a high extent. (Huirong et al., 2019) detailed that the correct method of milking is essential to lessen the occurrence of mastitis. The considered variables were decided as hazard components influencing mastitis as a breed, age, season, environment, management and hygiene (Pitkala et al., 2004; Sharif et al., 2007) recorded microbial growth in $21-33 \%$ of milk samples, whereas, just $15.16 \%$ identified in dairy buffaloes (lqbal et al., 2004). This disparity may be due to the climate changes, farm management practices, the location, draught purpose, the difference in handling of samples and the use of antibiotics.

Table 4. Associated risk factors of mastitis in cattle in and around Multan

\begin{tabular}{|c|c|c|c|c|}
\hline Variable & Number examined $n=100$ & Negative (\%) & Positive (\%) & P-value \\
\hline \multicolumn{5}{|c|}{ Production system } \\
\hline Semi-intensive & 30 & $16(53.3)$ & $14(46.6)$ & \multirow[t]{2}{*}{0.059} \\
\hline Intensive & 70 & $46(65.1)$ & $24(34.2)$ & \\
\hline \multicolumn{5}{|l|}{ Floor type } \\
\hline Earthen & 25 & $10(40)$ & $15(60)$ & \multirow[t]{2}{*}{0.402} \\
\hline concrete & 75 & $52(69.3)$ & $23(30.6)$ & \\
\hline \multicolumn{5}{|c|}{ Cleaning of floor } \\
\hline Daily & 80 & $54(67.5)$ & $26(32.5)$ & \multirow[t]{2}{*}{0.122} \\
\hline Weekly & 20 & $8(40)$ & $12(60)$ & \\
\hline \multicolumn{5}{|l|}{ Teat dips } \\
\hline Yes & 40 & $28(70)$ & $12(30)$ & \multirow{2}{*}{$0.01^{*}$} \\
\hline No & 60 & $35(58.3)$ & $25(41.6)$ & \\
\hline \multicolumn{5}{|l|}{ Breed } \\
\hline Crosses & 35 & $23(65.7)$ & $12(34.3)$ & \multirow[t]{2}{*}{0.124} \\
\hline Exotic & 65 & $39(60)$ & $26(40)$ & \\
\hline \multicolumn{5}{|c|}{ Proper milking techniques } \\
\hline Yes & 84 & $55(65.4)$ & $29(34.5)$ & \multirow[t]{2}{*}{0.001} \\
\hline No & 16 & $7(43.7)$ & $9(56.3)$ & \\
\hline \multicolumn{5}{|c|}{ History of mastitis } \\
\hline No & 68 & $43(63.2)$ & $25(36.8)$ & \multirow[t]{2}{*}{0.026} \\
\hline Yes & 32 & $19(59.4)$ & $13(40.6)$ & \\
\hline
\end{tabular}

Table 5. Antibiotic sensitivity test for E. coli $(\mathrm{n}=10)$ and $S$. aureus $(\mathrm{n}=15)$

\begin{tabular}{|l|l|l|l|l|l|l|l|}
\hline Antibiotics & \multirow{2}{*}{$\begin{array}{l}\text { Units } \\
\end{array}$} & \multicolumn{3}{|c|}{ E. coli } & \multicolumn{3}{|c|}{ S. aureus } \\
\cline { 3 - 8 } & 25 & $\mathrm{~S}(\%)$ & $\mathrm{I}(\%)$ & $\mathrm{R}(\%)$ & $\mathrm{S}(\%)$ & $\mathrm{I}(\%)$ & $\mathrm{R}(\%)$ \\
\hline Chloroamphencol & 25 & $-60 \%)$ & - & $4(40 \%)$ & $15(100 \%)$ & - & - \\
\hline Vancomycin & 30 & - & - & $10(100 \%)$ & $15(100 \%)$ & - & - \\
\hline Gentamycine & 15 & $10(100 \%)$ & - & - & $2(13.3 \%)$ & - & $13(86.7)$ \\
\hline Kanamycin & 30 & $7(70 \%)$ & - & $3(30 \%)$ & $15(100 \%)$ & - & - \\
\hline Streptomycin & 15 & $10(100 \%)$ & - & - & - & $3(20)$ & $12(80 \%)$ \\
\hline Penicillin & 10 & - & - & $10(100 \%)$ & - & - & $15(100 \%)$ \\
\hline Tetracycline & 30 & - & $4(4 \%)$ & $6(60 \%)$ & - & - & $15(100 \%)$ \\
\hline
\end{tabular}


In the present analysis, $S$. aureus was isolated from cases positive for mastitis as the top-ranking pathogen $(32.66 \%)$. It was also identified as a major pathogen in earlier studies (Ebrahimi et al., 2007; Mpatswenumugabo et al., 2017; Vakkamaki et al., 2017; El-jakee et al., 2019), reported $9.44 \%$ E. coli and $8.33 \%$ Strep. agalactiae isolates from subclinical mastitis milk specimens while(Suleiman et al., 2018) gained 42.6 percent $S$. aureus and 30\% growth of Strep. agalactiae and Strep. Strep. dysgalactiae. The primary cause of coliforms is polluted farm environments and they mostly cause clinical infections. (Vakkamaki et al., 2017) obtained 8.33\% Streptococci, 3.88\% CNS other than E. coli and $9.44 \%$ Strep. Agalactiae (Botrel et al., 2009) from subclinical mastitis milk samples, 13.7 percent coagulase-negative staphylococci, $30.2 \%$ CNS and $9.3 \%$ Strep. dysgalactiae were tested. The control programmes for mastitis recorded in recent years will need to be examined in accordance with our farming systems and local requirements. In this study, $E$. coli isolates were sensitive to Gentamycine, Streptomycin, Chlororamphenicol and Kanamycin while resistant to Vancomycin and Penicillin. Similarly, S. aureus was extremely susceptible to Chloramphenicol, Vancomycin and Kanamycin but resistant to tetracycline and Penicillin. These results were analogous to earlier researches (Seyoum et al., 2018; Kalayu et al., 2020).

It was concluded that subclinical mastitis was widely prevalent in Multan city. The lack of proper milking techniques and no teat dipping were the most significantly associated risk factors. E. coli isolates were sensitive to Gentamycine, Streptomycin, Chlororamphenicol and Kanamycin while resistant to Vancomycin and Penicillin whereas $S$. aureus was highly susceptible to Chloramphenicol, Vancomycin and Kanamycin but resistant to Tetracycline and Penicillin. This study will help the farmers to adopt effective measures to control mastitis in cattle.

\section{ACKNOWLEDGEMENTS}

The authors wish to acknowledge Directorate of Research, Bahauddin Zakariya University, Multan, Pakistan for supporting this research (Project number: DR and EL/D-740).

\section{AUTHOR'S CONTRIBUTION}

T. Ahmed: Designed the study and won the project/grant
M. Kashif: Performed analysis of data and write up

E. Ahmad: Performed the microbiological test and interpreted the data

M. Nadeem: Executed the experiments and analyzed the data

M. Rizwan: Sample collection and performed screening tests

\section{REFERENCES}

Dagmara, A., M. P. Niedziela, J. G. Murphy, M. Orla and C. L. Keane. 2020. Clinical presentation and immune characteristics in first-lactation Holstein-Friesian cows following intramammary infection with genotypically distinct Staphylococcus aureus strains. Journal of Dairy Science, 103 (9): 8453-8466.

Abebe, R., H. Hatiya and M. Abera. 2016. Bovine mastitis: prevalence, risk factors and isolation of Staphylococcus aureus in dairy herds at Hawassa milk shed, South Ethiopia. BMC Veterinary Research, 12 (1): 1-11.

Amer, S., F. L. A. Gálvez and Y. Fukuda. 2018. Prevalence and etiology of mastitis in dairy cattle in El Oro Province, Ecuador. Journal of Veterinary Medical Science, 80 (6): 861868.

Ashfaq, M., A. Razzaq, S. Haq and G. Muhammad. 2015. Economic analysis of dairy animal diseases in Punjab: A case study of Faisalabad district. Journal of Animal and Plant Sciences, 25 (5): 14821495.

Bachaya, H. A., M. A. Raza, M. Murtaza and U. R. Akbar. 2011. Subclinical bovine mastitis in Muzaffar-Garh district of Punjab, (Pakistan). Journal of Animal and Plant Sciences, 21 (1): 16-19.

Biswadeep, J., P. N. Kumar, S. Abhishek and A. Abrar. 2015. Subclinical Bovine Mastitis in Rural, Peri-Urban and Suburban Regions of Jaipur district of Rajasthan India. Journal of Animal Research, 5 (1): 175-182.

Botrel, M. A., M. Haenni, E. Morignat, P. Sulpice, J. Y. Madec and D. Calavas. 2009. Distribution and antimicrobial resistance of clinical and subclinical mastitis pathogens in dairy cows in Rhône-Alpes, France. Food borne Pathogens and Disease, 77 (5): 479487.

Cha, E., D. Bar, J. A. Hertl, L. W. Tauer, G. Bennett, R. N. González, Y. H. Schukken, F. L. Welcome and Y. T. Gröhn. 2011. The 
cost and management of different types of clinical mastitis in dairy cows estimated by dynamic programming. Journal of Dairy Science, 94 (9): 4476-4487.

Christine, M., C. Mbindyo, C. George, C. M. Gitao, and H. Mulei. 2020. Prevalence, Etiology, and Risk Factors of Mastitis in Dairy Cattle in Embu and Kajiado Counties, Kenya. Veterinary Medicine International, ID 8831172: 1-12..

DeVliegher, S., L. k. Fox, S. Piepers, S. McDougall and H. W. Barkema. 2012. Mastitis in dairy heifers: Nature of the disease, potential impact, prevention, and control. Journal of Dairy Science, 95 (3): 1025-1040.

Dorota, A., H. S. Charlotte, S. Emanuelson and R. Lars. 2020. Comparison of methods for predicting cow composite somatic cell counts. Journal of Dairy Science, 103 (9): 8433-8442.

Ebrahimi, A., K. H. P. Kheirabadi and F. Nikookhah. 2007. Antimicrobial susceptibility ofenvironmental bovine mastitis pathogens in west central Iran. Pakistan Journal of Biological Sciences, 10 (17): 3014-3016.

El-jakee, J. K., N. E. Aref and A. Gomaa. 2019. Emerging of coagulase negative staphylococci as a cause of mastitis in dairy animals: an environmental hazard. International Journal of Veterinary Science and Medicine, 1 (2): 74-78.

Hoque, M. N., Z. C. Das, A. K. Talukder, M. S. Alam and M. A. Rahman. 2015. Different screening tests and milk somatic cell count for the prevalence of subclinical bovine mastitis in Bangladesh. Tropical Animal Health and Production, 47 (1): 79-86.

Huirong, H., S. Da-Wen, P. Hongbin, C. Lijun and L. Li. 2019. Applications of Raman spectroscopic techniques for quality and safety evaluation of milk: A review of recent developments. Critical Reviews in Food Science and Nutrition, 59 (5): 770-793.

lqbal, M., M. A. Khan, B. Daraz and U. Siddique. 2004. Bacteriology of mastitic milk and in vitro antibiogram of the isolates. Pakistan Veterinary Journal, 24 (4): 1098-1134.

Kalayu, A. A., D.A. Woldetsadik, Y. Woldeamanuel, S. H. Wang, W. A. Gebreyes and T. Teferi. 2020. Burden and antimicrobial resistance of $\mathrm{S}$. aureus in dairy farms in Mekelle, Northern Ethiopia. BMC Veterinary Research, 16 (1): 20.

Kashif, M., T. Ahmad, A. Shakoor, M. Younus, A. Yousaf, M. Yaqoob, M. M. Awais, S. A.
Muhammad, A. Nasir and Z. Iqbal. 2013. Comparative efficacy of Enrofloxacin and Oxytetracycline as systemic dry period therapy for the control of bubaline mastitis. Buffalo Bull, 32 (2): 1002-1008.

Kavitha, K. L., K. Rajesh, K. Suresh, K. Satheesh and N. Syama Sunder. 2009. Buffalo mastitis- Risk factors. Buffalo Bull, 28 (3): 34-137.

Motaung, T., K. Petrovski, L. Petzer, O. Thekisoe and T. Tsilo. 2017. Importance of bovine mastitis in Africa. Anim. Health Res. Rev, 18 (1): 58-69

Mpatswenumugabo, J. P., L. C. Bebora and G. C. Gitao. 2017. Prevalence of subclinical mastitis and distribution of pathogens in dairy farms of Rubavu and Nyabihu districts, Rwanda. Journal of Veterinary Medicine, 81: 340-348.

Patil, M. P., A. S. Nagvekar, S. D. Ingole, S. V. Bharucha and V. T. Palve. 2015. Somatic cell count and alkaline phosphatase activity in milk for evaluation of mastitis in buffalo, Veterinary World, 8 (3): 363-366.

Pitkala, A., M. Haveri, S. Pyorala, V. Myllys and T. H. Buzalski. 2004. Bovine Mastitis in Finland, Prevalence, Distribution of Bacteria, and Antimicrobial Resistance. Journal of Dairy Science, 87 (8): 2433-2441.

Rohmeier, L., W. Petzl, M. Koy, T. Eickhoff, A. Hülsebusch, S. Jander, L. Macias, A. Heimes, A.Engelmann, S. Hoedemaker, M. Seyfert, H. M.Kühn, C. Schuberth, H. J. Zerbe and M. M. Meyerholz. 2020. In vivo model to study the impact of genetic variation on clinical outcome of mastitis in uniparous dairy cows. BMC Veterinary Research, 16 (1): 10-20.

Seyoum, B., H. Kefyalew, B. Abera and N. Abdela. 2018. Prevalence, risk factors and antimicrobial susceptibility test of Staphylococcus aureus in Bovine cross breed mastitic milk in and around Asella town, Oromia regional state, southern Ethiopia. Acta tropica, 177: 32-36.

Sharif, A., T. Ahmed, M. Q. Bilali, A. Yousuf and G. Muhammad. 2007. Effect of Severity of sub-clinical mastitis on somatic cell count and lactose contents of buffalo milk. Pakistan Veterinary Journal, 27 (3): 142144.

Suleiman, T. S., E. D. Karimuribo and R. H. Mdegela. 2018. Prevalence of bovine subclinical mastitis and antibiotic susceptibility patterns of major mastitis pathogens isolated in Unguja island of 
Zanzibar, Tanzania, Trop. Animal Health Production, 50 (2): 259-266.

Zeryehun, T. and A. Gerema. 2017. Prevalence and bacterial isolates of mastitis in dairy farms in selected Districts of Eastern Harrarghe Zone, Eastern Ethiopia. Journal of Veterinary Medicine, 31: 23-30.

Vakkamäki, J., S. Taponen, A. M. Heikkilä and S. Pyörälä. 2017. Bacteriological etiology and treatment of mastitis in Finnish dairy herds. Acta Veterinaria Scandinavica, 59 (1): 1-9.

Welderufael, B. G., D. J. Koning, L. L. Janss, W. F. Franzén and Fikse. 2016. Simultaneous genetic evaluation of simulated mastitis susceptibility and recovery ability using a bivariate threshold sire model. Animal Science, 66 (3): 125-134.

(Received: January 27, 2021; Accepted: May 17, 2021) 